\title{
In vitro cytotoxicity of the Synthesized Gallic Acid Derivatives ( N-Alkyl Gallamide) Against Breast MCF-7 Cancer Cells
}

\author{
MAURIN MARCELIA ${ }^{1}$, ADE ARSIANTI ${ }^{2,3 *}$, JILLY OCTARIA TAGORE CHAN ${ }^{1}$, STEVANO \\ JULIO WIJOYO', FADILAH FADILAH ${ }^{2,3}$, RISTA PUTRIANINGSIH ${ }^{2}$, NORMA NUR AZIZAH ${ }^{3}$, \\ ANTON BAHTIAR ${ }^{4}$, HIROKI TANIMOTO ${ }^{5}$ and KIYOMIKAKIUCHI $^{5}$
}

\author{
${ }^{1}$ Medical Student, Faculty of Medicine Universitas Indonesia, Indonesia. \\ ${ }^{2}$ Department of Medical Chemistry, Faculty of Medicine, Universitas Indonesia, Indonesia. \\ ${ }^{3}$ Drug Development Research Cluster, Indonesia Medical Education and Research Institute(IMERI), \\ Faculty of Medicine, Universitas Indonesia, Jl. Salemba Raya 6 Jakarta, Indonesia. \\ ${ }^{4}$ Department of Pharmacology, Faculty of Pharmacy, Universitas Indonesia, Depok, Indonesia. \\ ${ }^{5}$ Graduate School of Materials Science, Nara Institute of Science and Technology (NAIST), \\ 8916-5 Takayama-cho, Ikoma, Nara, Japan. \\ *Corresponding author E-mail: arsi_ade2002@yahoo.com \\ http://dx.doi.org/10.13005/ojc/340506
}

(Received: August 03, 2018; Accepted: September 04, 2018)

\begin{abstract}
Gallic acid is a phenolic compound distributed in plants and fruits which has been reported to have cytotoxic effect on MCF-7 breast cancer cell line. In this research, we investigated in vitro cytotoxic effect of six synthesized compounds of gallic acid derivatives ( $\mathrm{N}$-alkyl gallamide), namely $\mathrm{N}$-methyl gallamide (2); N-ethyl gallamide (3); N-butyl gallamide (4); N-sec-butyl gallamide (5); $\mathrm{N}$-tert-butyl gallamide (6) and N-hexyl gallamide (7) against breast MCF-7 cells by MTT assay. Linear regression analysis is utilized to analyze data to regenerate $I C_{50}$ value. The results will be compared with gallic acid as an original compound and doxorubicin as a positive control. Among six synthesized compounds, N-tert-butyl gallamide (6) with $\mathrm{IC}_{50}$ value of $2.1 \mu \mathrm{g} / \mathrm{mL}$, and $\mathrm{N}$-hexyl gallamide (7) with $\mathrm{IC}_{50}$ value of $3.5 \mu \mathrm{g} / \mathrm{mL}$, showed the stronger cytotoxicity against breast MCF-7 cells compared to gallic acid and doxorubicin. Thus, $\mathrm{N}$-tert-butyl gallamide (6) and $\mathrm{N}$-hexyl gallamide (7) are potential to be further developed as a promising anti-breast cancer agents.
\end{abstract}

Keywords: Cytotoxicity, Gallic acid derivative, N-alkyl gallamide, Breast MCF-7 cells, MTT assay.

\section{INTRODUCTION}

Breast cancer is a frequent diagnosed malignancy in females, and considerably the second most common human carcinoma in the world. In
2012, there were approximately 1.67 million of breast cancer cases which has increased by more than $20 \%$ since the 2008 estimates. It ranks fifth as a cause of death globally with estimated number of 522,000 deaths (13 per 100,000 population) during 
2012. Moreover, the death rate of breast cancer in women is higher in less developing areas (324,000 breast cancer deaths in 2012), and lower death rate in more developing areas $(198,000$ breast cancer deaths in 2012). Indonesia accounted for $17 \%$ of female breast cancer deaths within the Asia-Pacific Region in which 116,000 deaths occurred. ${ }^{1}$ The prognosis for female breast cancer depends on the stage. A five-year relative survival rate reaches until close to $100 \%$ for stage 0 and stage 1 . This rate moderately declines to $93 \%$ and $72 \%$ for stage II and stage III consecutively. Furthermore, five-year relative survival rate for female breast cancer patient on stage IV with metastatic is sharply drop to around $22 \% .^{2}$ Treatment choices for brest cancer include surgery, chemotherapy, and radiotherapy, however these treatments inconstantly successful and could produce unexpected side effects. ${ }^{3}$ Therefore, in order to improve the survival rate of patient as well as to reduce the side effects of the breast cancer treatment, the search for new molecules which show a stronger therapeutic reaction with minimum side effects compared to established ones are needed. Gallic acid (1) is a phenolic acid also known as 3,4,5-trihydroxybenzoic acid that has water soluble property and various biological activities, including an inhibitory effect against human breast cancer cells. ${ }^{4}$ Previously, studies have revealed that gallic acid prompted apoptosis in cancer cells as an accompaniment of oxidative stresses from mitochondrial dysfunction, Reactive oxygen species (ROS), and an incline in intracellular $\mathrm{Ca}^{2+}$ level ${ }^{5,6}$. The length of alkyl chain in ester side chain of gallic acid derivatives influenced the hydrophobicity and physicochemical properties of the derivatives. Alkyl ester gallates with longer alkyl chain would become more hydrophobic that will increase its affinity for the lipid bilayer of the cell membrane which allow the alkyl ester derivatives penetrate easier into the cell membrane of cancer cells than gallic acid. As evidence, the ester derivatives presented more favorable pharmacological properties than those for galllic acid itself due to enhancement of carbon atom lenght in alkyl ester side chain. However, a longer carbon chain in alkyl ester moiety causes a greater molecular weight of hydrophobic compound that less dissolved in water. ${ }^{7}$ Hence, molecular mechanisms underlying the action of gallic acid remain questionable.In the present study, we have done the synthesis of gallic acid derivatives as anti-hepatitis C virus agents. ${ }^{8}$ Recently, we also accomplished in silico docking study of gallic acid derivatives as inhibitor of malarial dihydrofolate reductase $^{9}$, as an inhibitors of hepatitis $C$ virus receptor binding target $\mathrm{NS} \mathrm{B}^{10}$, as an inhibitor of $\mathrm{Bcl}-\mathrm{xl}$ anti-apoptotic protein of breast cancer ${ }^{11}$, and as an inhibitor of BRAF colon cancer ${ }^{12}$. In this work, as to continue research in developing gallic acid derivatives as an anticancer agent, we focused on the cytotoxicity evaluation of $\mathrm{N}$-alkyl gallamide, compound 2-7 (Fig. 1) against MCF-7 cells by MTT cell proliferation assay. The synthesis of gallic acid derivatives, $\mathrm{N}$-alkyl gallamide (compound 2-7) applied in this study, have been completed recently by our research team. These alkyl amide derivatives of gallic acid demonstrated a strong cytotoxic effect on colon HCT- 116 cells. ${ }^{13}$

\section{EXPERIMENTAL}

\section{Synthesis of derivative2-7}

As reported previously, six gallic acid derivatives, compound 2-7 (Fig. 1) were designed by replacing carboxyl group of gallic acid with a series of corresponding alkylamines to generate $\mathrm{N}$-alkyl gallamide 2-7. Four compounds, namely derivative 2, 3, 4 and 7, were designed to have a linear aliphatic carbon chain in $\mathrm{N}$-alkyl benzamide group, whereas compound 5 and compound 6 were designed to have a branched alphatic carbon chain. ${ }^{13}$

Synthesis procedure, experimental data, and synthetic pathway of $\mathrm{N}$-alkyl gallamide 2-7 (Fig. 2) have been described in our previous work. ${ }^{13}$ As summarized in Fig. 2, amidation of gallic acid (1) with methylamine, ethylamine, butylamine, sec-butylamine, tert-butyl amine, and hexylamine using a combination of WSCD.HCl/HOBt in the presence of basic NMM afforded the corresponding $\mathrm{N}$-alkyl gallamides, which are $\mathrm{N}$-methylgallamide (2), N-ethyl gallamide (3), N-butyl gallamide (4), $\mathrm{N}$-sec-butyl gallamide (5), N-tert-butyl gallamide (6) and $\mathrm{N}$-hexyl gallamide (7) with a yield ranging from $18 \%$ to $84 \% .^{13}$ 


\section{MTT Assay in Determining the Cytotoxicity}

For the MTT assay, $1 \times 10^{6}$ cells/well were seeded into a 96-well cell plate in a total volume of $100 \mu \mathrm{L}$ for 24 hours. The medium was then removed, and the cells were treated with the following $\mathrm{N}$-alkyl gallamides: $\mathrm{N}$-methyl, $\mathrm{N}$-ethyl, $\mathrm{N}$-butyl, $\mathrm{N}$-sec-butyl, $\mathrm{N}$-tert-butyl, $\mathrm{N}$-hexyl gallamides at concentrations ranging from 1.5 to $200 \mu \mathrm{g} / \mathrm{mL}$. After $24 \mathrm{~h}$ incubation, the medium was removed while $100 \mu \mathrm{L}$ of MTT was added to each well, followed by a 2- to $4-\mathrm{h}$ incubation period. MTT solution was then discarded and added with $100 \mu \mathrm{L}$ DMSO. The absorbance was then measured at $630 \mathrm{~nm}$ using ELISA reader. Data of cell growth inhibition were provided as the average<smiles>O=C(O)c1cc(O)c(O)c(O)c1</smiles><smiles>CNC(=O)c1cc(O)c(O)c(O)c1</smiles>
$N$-methyl gallamide (2)<smiles>CCC(C)NC(=O)c1cc(O)c(O)c(O)c1</smiles>

N-sec-butyl gallamide (5)<smiles>CCNC(=O)c1cc(O)c(O)c(O)c1</smiles>

$N$ - ethyl gallamide (3)<smiles>CC(C)(C)NC(=O)c1cc(O)c(O)c(O)c1</smiles>

N-tert-butyl gallamide (6)<smiles>CCCCNC(=O)c1cc(O)c(O)c(O)c1</smiles>

N- butyl-gallamide (4)<smiles>CCCCCCNC(=O)c1cc(O)c(O)c(O)c1</smiles>

$N$-hexyl gallamide (7)

Fig. 1. Structure of gallic acid (1) and its $\mathrm{N}$-alkyl amide derivatives 2-7

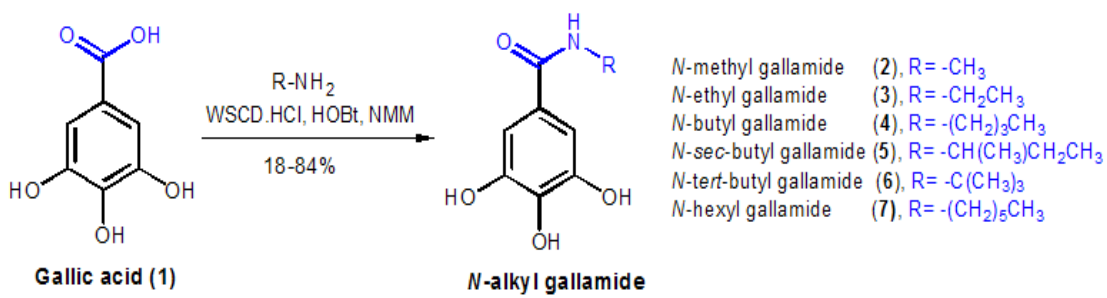

Fig. 2. Synthetic pathway of derivatives2-7

\section{RESULT AND DISCUSSION}

In vitro cytotoxicities of 3,4,5-trihydroxy$\mathrm{N}$-alkyl-benzamides against breast MCF-7 cancer cellsis displayed in Table 1. Cytotoxicities expressed by half maximal inhibitory concentration $\left(\mathrm{IC}_{50}\right)$ value. The lower $\mathrm{IC}_{50}$ value the stronger cytotoxic activity.
Atjanasuppat et al., reported that cytotoxicity of compound were categorized into four groups based on $I_{50}$ value. $I_{50}$ value below or equal 20 $\mu \mathrm{g} / \mathrm{mL}$, strong cytotoxic activity; IC50 value in range of 20 to $100 \mu \mathrm{g} / \mathrm{mL}$, moderate cytotoxic activity; IC50 value ranging from 100 to $1000 \mu \mathrm{g} / \mathrm{mL}$, weak cytotoxic activity; and $\mathrm{IC}_{50}$ value over than 1000 
$\mu \mathrm{g} / \mathrm{mL}$, shows no cytotoxic activity. ${ }^{14}$ From the result of this experiment, as shown in Table 1, all $\mathrm{N}$-alkyl gallamides (compound 2-7) exhibited a strong cytotoxic activity against breast MCF-7 cancer cells as all of the $\mathrm{IC}_{50}$ values were below $20 \mu \mathrm{g} / \mathrm{mL}$.

\section{Effect of chain length in cytotoxic property}

As shown in Table 1, generally the cytotoxicity of derivatives that have a linear aliphatic carbon chain in $\mathrm{N}$-alkyl gallamides greatly improved by addition of carbon chain in $\mathrm{N}$-alkyl moiety. It can be observed from $\mathrm{IC}_{50}$ value of $\mathrm{N}$-methyl gallamide 2 $\left(\mathrm{IC}_{50}: 12.6 \mu \mathrm{g} / \mathrm{mL}\right)$, - $\mathrm{N}$-ethyl gallamide $3\left(\mathrm{IC}_{50}: 11.3\right.$ $\mu \mathrm{g} / \mathrm{mL})$, - $\mathrm{N}$-butyl gallamide $4\left(\mathrm{IC}_{50}: 10.3 \mu \mathrm{g} / \mathrm{mL}\right)$ and $\mathrm{N}$-hexyl-gallamide $7\left(\mathrm{IC}_{50}: 3.5 \mu \mathrm{g} / \mathrm{mL}\right)$ consecutively, which are decreasing by addition of carbon chain in $\mathrm{N}$-alkyl-benzamide group. This suggested that as the carbon chain is longer, the derivative become more non-polar, its permeability towards cell membrane was greatly increased, which lead to the increasement of its cytotoxicity against MCF-7 cancer cells.

\section{Effect of chain branching in cytotoxic property}

Derivatives with a branched carbon chain in $\mathrm{N}$-alkyl benzamide group shows a greater cytotoxicity compared to derivatives with a linear carbon chain. It can be observed on the branched-chain four-carbon of $\mathrm{N}$-sec-butyl gallamide 5 with $\mathrm{IC}_{50}$ value of 8.4 $\mu \mathrm{g} / \mathrm{mL}$, and N-tert-butyl gallamide 6 with $\mathrm{IC}_{50}$ value of $2.1 \mu \mathrm{g} / \mathrm{mL}$, which have a greater cytotoxicity than $\mathrm{N}$-butyl gallamide $4\left(\mathrm{IC}_{50}: 10.3 \mu \mathrm{g} / \mathrm{mL}\right)$ which also has four-carbon chain, but with a linear structure.

Another study that gave similar results was a study conducted by Frey et al., which proved that isobutylgallate had lower $\mathrm{IC}_{50}$ value compared with butyl gallate against sarcoma 786A,TA3 and TA3-MTX-R tumor cells. Correspondingly, cytotoxic activity of isoamyl and isopropyl gallate were stronger than the cytotoxicity of amyl and propyl gallate. ${ }^{15}$

The addition of branch into the derivative of gallic acid will change the solubility. Chain branching allows the compound to be more lipophilic owing to the decreasing the polarity, thus making it easier to penetrate the lipid bilayer. ${ }^{16}$
Among the six synthesized derivatives, $\mathrm{N}$-tert-butyl gallamide 6 and N-hexyl gallamide 7 showed a greater cytotoxicity against breast MCF-7 cells than gallic acid $\left(\mathrm{IC}_{50}: 7.5 \mu \mathrm{M}\right)$ and doxorubicin $\left(\mathrm{IC}_{50}: 10.6 \mu \mathrm{M}\right)$ as a positive control. These results indicated that modifying the carboxyl group of gallic acid become a branched-alkyl chain with four carbon atom in N-tert-butyl gallamide 6 , and become a linear-alkyl chain with six carbon atom in $\mathrm{N}$-hexyl gallamide 7 , have successfully improved its cytotoxicity against breast MCF-7 cancer cells. Thus, $\mathrm{N}$-tert-butyl gallamide 6 and N-hexyl gallamide 7 are potential to be further developed as anti-breast cancer drugs.

Table 1: Cytotoxicities ( $\mathrm{IC}_{50}$ in $\mu \mathrm{g} / \mathrm{mL}$ ) of $\mathrm{N}$-alkyl gallamides 2-7, gallic acid (1), and doxorubicin against breast MCF-7 cells

\begin{tabular}{lcc}
\hline Compound & \multicolumn{1}{c}{ Cytotoxicity $\left(\mathrm{IC}_{50}, \mu \mathrm{g} / \mathrm{mL}\right)$} \\
\hline Gallic acid (1) & & 7.5 \\
N-methyl gallamide & $(2)$ & 12.6 \\
N-ethyl gallamide & $(3)$ & 11.3 \\
N-butyl gallamide & $(4)$ & 10.3 \\
N-sec-butyl gallamide (5) & 8.4 \\
N-tert-butyl gallamide & $(6)$ & 2.1 \\
N-hexyl gallamide & $(7)$ & 3.5 \\
Doxorubicin & & 10.6 \\
\hline
\end{tabular}

CONCLUSION

Six synthesized gallic acid derivatives of $\mathrm{N}$-alkyl gallamide have been evaluated on their basis of cytotoxicity against breast MCF-7 cells. Among six derivatives, N-tert-butyl gallamide (6) and N-hexyl gallamide (7) showed a greater cytotoxicity against breast MCF-7 cells.

\section{ACKNOWLEDGEMENT}

We sincerely thank to Directorate of Research and Community Engagement (DRPM) and Faculty of Medicine, Universitas Indonesia for the PITTA research grant. We also thank to Division of Materials Science, Nara Institute of Science and Technology (NAIST), Japan, for NAIST Global Collaborative Research Program.

\section{REFERENCE}

1. Ferlay, J.; Soerjomataram, I.; Ervik, M.; Dikshit, R.; Eser, S.; Methers, C. GLOBOCAN v1.0,
Canceer Incidence and Mortality Worldwide: IARC CancerBase No.11 [Internet]. Lyon, 
France: International Agency for Research on Cancer, Available from: http://globocan. iarc.fr., 2013.

2. American Cancer Society. Breast Cancer Survival Rates by Stage [Internet]. Available from: http://www.cancer.org/cancer/breast cancer/detailedguide/breast-cancer-survivalby-stage., 2014.

3. Cardoso, F.; Costa, A.; Senkus, E.; Aapro, M.; Andre, F.; Barrios, C.H.; Bergh, J.; Bhattacharyya, G.; Biganzoli, L.; Cardoso, M.J.; Carey, L.3 ${ }^{\text {rd }}$ ESO-ESMO international consensus guidelines for Advanced Breast Cancer (ABC3). Ann. Oncol., 2017, 28, 16-33.

4. Wang, K.; Zhu, X.; Zhang, K.; Zhu, L.; Zhou, F. J. Biochem. Mol. Toxicol., 2014, 28, 387-393.

5. Inoue, M.;Sakaguchi, N.;Isuzugwa, K.;Tani, H.;Ogiwara, Y. Biol. Pharm. Bull., 2000, 23, 1153-1157.

6. Serrano, A.; Palacios, C.; Roy, G.;Cespon, C.;Villar, M.L;Nocito, M.; Gonzales-Porque, P. Arch. Biochem. Biophys., 1998, 350, 49-54.

7. Locatelli, C.;Filippin-Monteiro, F. B.;CreczynskiPasa, T.B. Eur. J. Med. Chem., 2013, 60, 233-239.

8. Arsianti, A.; Aoki-Utsubo,C.; Fadilah, F.; Bahtiar, A.; Apriyanto, D.R.; Dwira, S.; Pradisty, N.A.; Tanimoto, H.; Kakiuchi, K.; Sudarmono, P.; Hotta, H.; Paramita, R.I.;
Erlina, L. Asian J. Pharm. Clin. Res., 2017, 10, 164-167.

9. Arsianti, A.; Astuty, H.; Fadilah, F.; Bahtiar, A.; Tanimoto, H.; Kakiuchi, K. Asian J. Pharm. Clin. Res., 2017, 10, 330-334.

10. Arsianti, A.; Fadilah, F.; Bahtiar, A.; Dwira, S.; Apriyanto, D.R.; Paramita, R. I Int. J. Chemtech Res., 2017, 10, 111-117.

11. Paramita, R.I.; Arsianti, A.; Radji, M. Int. J. Chemtech Res., 2017, 10, 348-355.

12. Humaedi, A.; Arsianti, A.; Radji, M. Int. J. Chemtech Res., 2017, 10, 310-315.

13. Chan, J.O.T.; Arsianti, A.; Marcelia, M.; Wijoyo, S.J.; Fadilah, F.; Putrianingsih, R.; Azizah, N.N.; Tanimoto, H.; Kakiuchi, K. Orient. J. Chem., 2018, 34, 1362-1367.

14. Atjanasuppat, K.;Wongkham, W.;Meepowpan, P.;Kittakoop, P.;Sobhon, P.; Bartlett, A.; Whitfield. P. J. J. Ethnopharmacol., 2009; 123, 475-482.

15. Frey, C.;Pavani, M.;Cordano, G.; Munoz, S.; Rivera, E.; Medina, J. Comp. Biochem. Phys. A., 2007, 146, 520-527.

16. Mannhold, R.;Kubinyi, H.; Timmerman, H. editors. In: Todeschini, R.; Consonni, V.; Handbook of molecular descriptors methods and principal in medisinal chemistry. $11^{\text {th }}$ ed. German: Wiley-VCH., 2008. 